\title{
Limitation of activity and restriction of social participation in relation to age range, gender, and education in people with leprosy ${ }^{*}$
}

\author{
Bianca Manzan Reis ${ }^{1}$ \\ Luciane Fernanda Rodrigues Martinho Fernandes ${ }^{3}$
}

\author{
Shamyr Sulyvan de Castro ${ }^{2}$
}

DOI: http:/ / dx.doi.org/10.1590/abd1806-4841.20175216

\begin{abstract}
BACKGROUND: In Brazil, 38,000 new cases of leprosy are discovered each year, making it a public health problem. ОвлестіVE: To identify whether or not there is an association between activity limitations and the restriction of social participation with some demographic data (age range, gender, and education) of the patients in a Basic Health Unit (BHU), diagnosed with leprosy.

METHODS: The SALSA scale was used to assess activity limitations, whereas the Participation scale was used to assess the restriction of social participation.

RESULTS: The assessments were conducted with 31 BHU patients diagnosed with leprosy. Males were the most affected by leprosy, the multibacillary was the most prevalent, and education proved to be an important factor when related to the disease injuries among the evaluated individuals. Regarding activity limitations and the restriction of social participation, the percentage of individuals without limitations and without restrictions was greater in both scales.

STUDY LimitATIONS: The main limitation is the small study sample.

CONCLUSION: It can be concluded that, for the studied sample, no association was observed between the activity limitations, evaluated by the Salsa scale, nor the restriction of social participation, evaluated by the Participation Scale, with the analyzed demographic data.
\end{abstract}

Keywords: Activities of daily living; International classification of functioning, disability, and health; Leprosy; Social participation

\section{INTRODUCTION}

Leprosy is a chronic infectious and contagious disease of slow evolution. The causing agent of the disease is Mycobacterium leprae, an obligate intracellular parasite that affects the skin, the peripheral nerves, the mucosa of the upper respiratory tract, and the eyes. ${ }^{1}$ Its transmission occurs in untreated individuals who release the bacilli through upper airways. ${ }^{2}$ This microorganism possesses a high infectivity and a low pathogenicity, that is, it infects many people, but few fall ill. Approximately $90 \%$ to $95 \%$ of the population possess immunological resistance to the bacillus. Its period of incubation varies from two to seven years. ${ }^{3}$

According to the World Health Organization (WHO), ${ }^{4}$ leprosy is still present in 141 countries. In 2010, nearly 245,000 new cases were diagnosed. Currently, India presents the highest index, with an average of 134,000 new cases each year, followed by Brazil, with 38,000 new cases. For this reason, leprosy is still considered a public health problem. ${ }^{4}$ According to Datasus, 40,102 new cases were detected in Brazil in 2012. ${ }^{5}$
The classification of leprosy is used to define the polychemotherapy treatment: considered paucibacillary, when the patient has up to five lesions, and multibacillary, when the patient has more than five lesions. In addition to this classification, there are five clinical forms: undetermined, tuberculoid, pure neural, borderline, and lepromatous. ${ }^{6}$

Leprosy has an important repercussion in the peripheral nerves, and the neural inflammations (neuritis) are the main causing agents of disabilities. The identification of the neural impairment and of the patient's future disability is important for guidance regarding the regular practice of self-care and for the proper referral of the patient for appropriate treatment, when necessary. ${ }^{2}$

The motor and sensitive manifestations caused by neuritis lead, in some cases, to the occurrence of deficiencies in people diagnosed with the disease, with a probable loss in workforce, loss of activities and social participation, social esteem, and discrimination..$^{71}$ In this sense, it is important to determine the dimension and nature of these problems through specific periodic assessments, and with this, favor the carrying out of appropriate treatment to prevent

Received on 02.10 .2015 .

Approved by the Advisory Board and accepted for publication on 16.05.2016.

* Work conducted at the Eurico Vilela Basic Health Unit - Uberaba (MG), Brazil.

Financial Support: Proext/MEC/UFTM-2012.

Conflict of interests: None.

Department of Physical Therapy, Universidade Federal de São Carlos (UFSCar) - São Carlos (SP), Brazil.

Department of Physical Therapy, Universidade Federal do Ceará (UFC) - Fortaleza (CE), Brazil.

Department of Applied Physical Therapy, Instituto de Ciências da Saúde (ICS), Universidade Federal do Triângulo Mineiro - Uberaba (MG), Brazil. 
the appearance of deficiencies and disabilities. Some questionnaires are used for periodic assessments of people diagnosed with leprosy, such as the Salsa scale, employed in the assessment of activity limitations and the risk of increases in deficiencies, as well as the Participation scale, used in the assessment of restrictions to social participation..$^{12,13}$

With this information, healthcare services can offer holistic care to people with leprosy, addressing from the treatment of the disease to the rehabilitation and the patient's social insertion. This information can also serve as guiding marks in the planning of policies and health programs geared toward the prevention of leprosy, as well as its early detection and proper treatment. Therefore, this study seeks to identify if there is in fact an association between activity limitations and restrictions of social participation with some demographic data (age range, gender, and education) of the patients diagnosed with leprosy from the Dr. Eurico Vilela Basic Health Unit (BHU) in the city of Uberaba, MG, Brazil.

\section{METHODS}

The present study is cross-sectional, which was developed over a period of six months in the Dr. Eurico Vilela BHU in the city of Uberaba. This study used a convenience sample, in which all of the 31 individuals who received medicines for the treatment of leprosy at the BHU during the collection period were selected. This study was conducted during the extension project "ProHansen: Prevenindo e Assistindo a Hanseníase", at Universidade Federal do Triângulo Mineiro. The Ethics Committee for Research on Human Beings assessed and approved this study, logged under protocol number 1776, and the information was collected after the reading and signing of free and informed consent forms.

The patients were led individually to a room where the interviews were conducted and the data was collected. For data collection, a multiple choice questionnaire was drawn up with sociodemographic questions (gender, age range, education) and information about the operational classification. In addition, two assessment instruments were used: the Screening of Activity Limitation and Safety Awareness (Salsa) scale and the Participation scale. Data collection was conducted by only one previously trained examiner, and the questions were presented according to the guidelines set forth by the Brazilian Health Ministry. ${ }^{14}$

The Salsa scale is an instrument used in Brazil ${ }^{12}$ whose core aim is to conduct the triage of the extent of the activity limitation and the risk of increase in deficiencies in individuals diagnosed with leprosy, diabetes, and other peripheral neuropathies. This scale includes five domains, involving visual acuity, mobility (feet), selfcare, work (hands), and dexterity (hands), as well as contains two types of scores: the Salse score and the awareness and risk score. The Salsa score is calculated through the sum of partial scores of the YES answer groups (one point for each answer of "easy"; two points for each answer of "a little difficult"; three points for each answer of "very difficult"), and NO answer groups (zero for each answer of "I don't need to do this" and four points for each answer of "I cannot physically do this" or "I avoid this because of the risk"). In this manner, the Salsa score varies from 1 point to 80 points, with the results classified as: no limitation (zero to 24 points); with mild limitation
(25 to 39 points); with moderate limitation (40 to 49 points); with severe limitation (50 to 59 points); and with very severe limitation (60 to 80 points). ${ }^{12}$ The awareness and risk score was not used in this study.

The participation scale is used to measure the restriction to social participation of individuals diagnosed with leprosy, deficiencies, or other stigmatizing conditions. The scale was translated and validated in Brazil and encompasses eight of the nine main areas of everyday activities defined in the International Classification of Functioning (ICF). ${ }^{6}$ The final score of the participation scale varies from 0 to 90 points, with the following representation: from $0-12$ points, the individuals presents no restrictions to participation; from 13 to 22 points, there is a mild restriction; from 23 to 32 points, there is a moderate restriction; from 33 to 52 points, there is a major restriction; and 53 to 90 points, there is an extreme restriction. ${ }^{6,13}$

To analyze the sociodemographic profile, the following variables were considered: gender, age range, operational classification, and education. The age range variable was categorized in two levels, considering the median, while the education variable was also categorized in two levels: elementary (incomplete or complete) and high school (incomplete). None of the individuals presented a complete high school education. In the Salsa scale, 10 individuals present mild limitations; three, moderate limitations; and one, very severe limitations. The 17 remaining participants presented no limitations. The results of the scale's partial scores, classified as "with mild limitations", "with moderate limitations". "with severe limitations", and "with very severe limitations", were grouped together and called "with limitations", while the results of "without limitations" remained the same. In the participation scale, the results "with mild restrictions", "with moderate restrictions", "with major restrictions", and "with extreme restrictions" were grouped together and called "with restrictions", while the results of "without restrictions" remained the same. The data were stored and treated, using the Stata 10 software. The sociodemographic data and the scores from the scales were analyzed by means of a non-parametric chi-square test, with a significance level of $5 \%$.

\section{RESULTS}

In total, 31 individuals were evaluated, with an average age of $51( \pm 17)$ years and a median of 56 years. The larger number of cases was found in males (61.3\%), and the multibacillary classification was predominant $(80.6 \%)$.

For the Salsa scale, the total number of individuals without limitations was greater when compared to the total number of individuals without limitations. Regarding gender, $50 \%$ of the women and $42 \%$ of the men presented limitations. In the division of age ranges, there was a larger number of individuals with limitations in the age range from 29 to 55 years. A greater number of individuals with limitations was identified in the multibacillary than in the paucibacillary classification; however, this increase proved to be insignificant. As regards education, of the total number of individuals with limitations, $83.3 \%$ had only an elementary education (Table 1 ).

For the analysis of the participation scale, 23 (74.19\%) presented no restrictions. As regards gender and age range, results were similar when compared to having restrictions or not. A great- 
er percentage of individuals without restrictions was found in the multibacillary classification (Table 2).

The greater number of individuals have studied until, but did not complete, high school, and it was at this education level that the largest number of individuals was identified with limitations in the Salsa scale and with restrictions in the Participation score was identified. No association of sociodemographic variables (gender, age range, operational classification, and education) was observed with the results from the Salsa scale and the Participation scale (Tables 1 and 2).

\section{DISCUSSION}

The population of this study consisted mostly of men $(61.29 \%)$, presenting a similarity with that from other studies. ${ }^{15-17}$ The proportion between men and women who have been affected in Brazil is of 1.3:1.0. ${ }^{18}$ According to Noordeen, this is due to the lifestyle of men, who expose themselves to greater risks of infection. ${ }^{19}$ Hence, biological and economic factors, and especially differences in the sociocultural behavior between the genders, may well be related to the greater detection of cases in the male population. ${ }^{20}$

As regards the operational classification and gender, a greater number of multibacillary cases were found in men, which runs in line with findings from Costa, ${ }^{20}$ Barbosa et al. ${ }^{21}$ and Moschioni. ${ }^{22}$ The multibacillary form is a signal that the disease received a late diagnosis, thus favoring the maintenance of the transmission chain, given that it is considered to be the main means of disease transmission. By contrast, the predominance of the paucibacillary form indicates that the disease received an early diagnosis, thus diminishing its transmission chain. ${ }^{23}$ In this sense, it is important for programs and healthcare policies geared toward men's health to emphasize the need for prevention, early detection, and treatment of leprosy.

Through the Salsa scale, this study found $54.84 \%$ of the individuals without limitations and $45.16 \%$ with limitations. The same was observed in a study conducted by Barbosa et al., ${ }^{21}$ in which the cases without limitations stand out (59.4\% of the patients), whereas severe limitations were found in only $4.2 \%$ of the patients. How-

\begin{tabular}{|c|c|c|c|c|c|c|c|}
\hline \multirow[t]{2}{*}{ Variables $^{1}$} & \multicolumn{2}{|c|}{ Without limitations } & \multicolumn{2}{|c|}{ With limitations } & \multicolumn{2}{|l|}{ Total } & \multirow[t]{2}{*}{$\mathbf{P}^{2}$} \\
\hline & n (17) & $\%(54.84)$ & n (14) & $\%(45.16)$ & n (31) & $\%(100)$ & \\
\hline Sex & & & & & & & 0.5810 \\
\hline Female & 6 & 50 & 6 & 50 & 12 & 100 & \\
\hline Male & 11 & 57,89 & 8 & 42.11 & 19 & 100 & \\
\hline Age range (years) ${ }^{3}$ & & & & & & & 0.6842 \\
\hline $29-55$ & 9 & 60 & 6 & 40 & 15 & 100 & \\
\hline $56-86$ & 8 & 50 & 8 & 50 & 16 & 100 & \\
\hline Operational classification & & & & & & & 0.2490 \\
\hline Multibacillary & 13 & 52 & 12 & 48 & 25 & 100 & \\
\hline Paucibacillary & 4 & 80 & 1 & 20 & 5 & 100 & \\
\hline Education & & & & & & & 0.5814 \\
\hline Incomplete $\mathrm{EE}^{4}$ & 11 & 52.38 & 10 & 47.62 & 21 & 100 & \\
\hline $\begin{array}{l}\text { Incomplete or } \\
\text { complete HS }\end{array}$ & 4 & 66.67 & 2 & 33.33 & 6 & 100 & \\
\hline
\end{tabular}

${ }^{1}$ One of the subjects had no operational classification and was excluded. ${ }^{2}$ Chi-square test. ${ }^{3}$ Variable categorized by the median. ${ }^{4}$ EE $=$ elementary education. ${ }^{5} \mathrm{HS}=$ high school

TABLE 2: Distribution of gender, age range, operational classification, and education according to the grouped classification of the Participation scale. Uberaba, 2012

\begin{tabular}{|c|c|c|c|c|c|c|c|}
\hline \multirow[t]{2}{*}{ Variables $^{1}$} & \multicolumn{2}{|c|}{ Without restrictions } & \multicolumn{2}{|c|}{ With restrictions } & \multicolumn{2}{|l|}{ Total } & \multirow[t]{2}{*}{$\mathbf{P}^{2}$} \\
\hline & n (23) & $\%(74.19)$ & n (8) & $\%(25.81)$ & n (31) & $\%(100)$ & \\
\hline Sex & & & & & & & 0.9350 \\
\hline Female & 9 & 75 & 3 & 25 & 12 & 100 & \\
\hline Male & 14 & 73.68 & 5 & 23.62 & 19 & 100 & \\
\hline Age range $^{3}$ (years) & & & & & & & 0.8769 \\
\hline $29-55$ & 11 & 77.78 & 4 & 22.22 & 15 & 100 & \\
\hline $56-86$ & 12 & 75 & 4 & 25 & 16 & 100 & \\
\hline Operational classification & & & & & & & 0.4600 \\
\hline Multibacillary & 19 & 76 & 6 & 24 & 25 & 100 & \\
\hline Paucibacillary & 3 & 60 & 2 & 40 & 5 & 100 & \\
\hline Education & & & & & & & 0.5847 \\
\hline Incomplete or complete $\mathrm{EE}^{4}$ & 14 & 64.71 & 7 & 35.29 & 21 & 100 & \\
\hline Incomplete HS ${ }^{5}$ & 5 & 100 & 1 & 0 & 6 & 100 & \\
\hline
\end{tabular}

${ }^{1}$ One of the subjects had no operational classification and was excluded. ${ }^{2}$ Chi-square test. ${ }^{3}$ Variable categorized by the median. ${ }^{4} \mathrm{EE}=$ elementary education. ${ }^{5} \mathrm{HS}=$ high school 
ever, Reis, Gomes, and Cunha ${ }^{24}$ found a Salsa score of equal to or greater than 25 in $91.7 \%$ of the sample, indicating some degree of limitation. Upon assessing the degree of limitation as compared to gender, $50 \%$ of the women and $42.2 \%$ of the men presented limitations. In findings from Moura, $58.2 \%$ of the women presented no activity limitations. ${ }^{25}$

As regards the age range, $40 \%$ of the individuals from 29 to 55 years of age, and $50 \%$ of the individuals from 56 to 86 years of age presented limitation. Mangueira found a decline in the limitations with the increase in age, and Barbosa highlighted that the relationship between the Salsa score and the age range proved to be insignificant. $^{26,27}$

Both in the present study and in that conducted by Ikehara, Ferrigno, Pedro, and Paschoal, the limitations with a greater index occurred in individuals with a multibacillary classification, showing that the individuals with a multibacillary classification should receive more attention from healthcare services in an attempt to diminish the impact of the disease on their functional and social activities. ${ }^{28}$

The Participation scale is based on ICF and allows one to have a broader and more well-rounded view of individuals diagnosed with leprosy. It provides a biopsychosocial approach, in addition to exposing the disabilities and functioning related to health conditions, bearing in mind some primary points concerning the activities and social participation in the environment in which the person lives. ${ }^{13}$ At the time of assessment, $74.19 \%$ of the total sample presented no type of restriction on the social participation scale. This information is similar to findings from a study conducted in China, in which the authors observed that $54 \%$ of the patients presented no restrictions during treatment. ${ }^{29}$ In Brazil, Barbosa et al. highlighted that $92.8 \%$ of the people diagnosed with leprosy had no restrictions in social participation after having been released from polychemotherapy. ${ }^{21} \mathrm{Ac}-$ cording to Barbosa, ${ }^{27}$ this most likely occurs due to the fact that the people presented greater difficulties in accepting the disease during the diagnosis and treatment. In our study, the individuals were still undergoing drug treatment, justifying a reduction in the percentage of those without restrictions as compared to the percentage found in the study conducted by Barbosa et al. ${ }^{21}$

This study found a predominance of individuals with an education up to an eighth grade, and this education level was the group that presented the largest limitations and restrictions, which is in accordance with findings from Moura. ${ }^{25}$ According to Moraes, the inferior educational level has been considered a risk factor for leprosy, given that the majority of these people do not adhere to the treatment. It is also considered to be a risk factor for the development of more severe forms of the disease. ${ }^{30}$ This information reinforces the need for specific actions of early prevention and detection for the populational segment with a lower education level.

It was observed that between the multibacillary cases, there was a lower number of individuals with restrictions when compared to the paucibacillary cases, which can be justified by the discrepancy between the number of paucibacillary and multibacillary cases. Because of this, it was not possible to characterize the groups separately.

No significant associations were found between the sociodemographic variables and the results from the assessed scales. The reduced sample can be presented as a factor for this result or as a limitation of this study. Nevertheless, it is important to note that this study evaluated all of the cases diagnosed in the municipality to which they were referred and followed up in the reference unit where this study was conducted. It is also important to emphasize that the knowledge of the profile of individuals diagnosed with leprosy in the city of Uberaba allows for healthcare professionals who work with the disease to understand their main illnesses and their main difficulties. In this manner, the professionals who work directly with rehabilitation can offer specialized care to patients with changes in their motor and sensory functions, or to those who already possess some type of deformity, in turn promoting their social reintegration, both through the recuperation of the function, as well as through the overcoming of deficiencies and disabilities imposed by leprosy. In addition, the results of this study provide information for the discussion, re-dimensioning, and proposal of treatment plans, policies, and healthcare programs, not only in Uberaba, but also in any city or healthcare service that wish to deal with the problem of leprosy in a more appropriate manner.

\section{CONCLUSION}

Therefore, it can be concluded that, for the studied samples, no association can be observed between activity limitations, assessed by the Salsa scale, nor between restrictions of social participation, assessed by the Participation scale, with the sociodemographic data analyzed in this study. As regards the sociodemographic data, men were more commonly affected by leprosy, the multibacillary form was predominant, and the education level was an important factor related to the harmful conditions of the disease among the assessed individuals. As regards activity limitations and restrictions of social participation, the percentage of individuals without limitations and without restrictions prevailed in both scales.] 


\section{REFERENCES}

1. Rodrigues LC, Lockwood DN. Leprosy now: epidemiology, progress, challenges, and research gaps. Lancet Infect Dis. 2011;11:464-70.

2. Ministério da Saúde. Secretaria de Atenção à Saúde. Departamento de Atenção Básica. Vigilância em Saúde: Dengue, Esquistossomose, Hanseníase, Malária, Tracoma e Tuberculose. 2. ed. rev. Brasilia: Ministério da Saúde; 2008. (Série A. Normas e Manuais Técnicos) (Cadernos de Atenção Básica, n. 21).

3. Barbieri CLA, Marques HHS. Hanseníase em crianças e adolescentes: revisão bibliográfica e situação atual no Brasil. Pediatria (São Paulo). 2009;31:281-90.

4. Who.int [Internet]. World Health Organization. Leprosy, situation and trends, 2014. [cited $20 \mathrm{Abr}$ 15]. Available from: http://www.who.int/gho/neglected_diseases/ leprosy/en/index.html.

5. Tabnet.datasus .gov [Internet]. Ministério da Saúde Secretária Executiva. Datasus. Informações de Saúde. Informações epidemiológicas e morbidade [acesso em 20 Abr 2015]. Disponível em: http://tabnet.datasus.gov.br/cgi/tabcgi.exe?sinannet/hanseniase/cnv/hanswmg.def

6. van Brakel WH, Anderson AM, Mutatkar RK, Bakirtzief Z, Nicholls PG, Raju MS, et. al. The Participation Scale: Measuring a key concept in public health. Disabil Rehabil. 2006;28:193-203.

7. Sarkar J, Dasgupta A, Dutt D. Disability among new leprosy patients, an issue of concern: An institution based study in an endemic district for leprosy in the state of West Bengal, India. Indian J Dermatol Venereol Leprol. 2012;78:328-34.

8. Monteiro LD, Alencar CHM de, Barbosa JC, Braga KP, Castro MD, Heukelbach J. Incapacidades físicas em pessoas acometidas pela hanseníase no período pós-alta da poliquimioterapia em um município no Norte do Brasil. Cad Saúde Pública. 2013;29:909-20.

9. Slim FJ, van Schie CH, Keukenkamp R, Faber WR, Nollet F. Effects of impairments on activities and participation in people affected by leprosy in the netherlands. $\mathrm{J}$ Rehabil Med. 2010;42:536-43.

10. Rafferty J. Curing the stigma of leprosy. Lepr Rev. 2005;76:119-26.

11. van Brakel WH, Sihombing B, Djarir H, Beise K, Kusumawardhani L, Yulihane R, et al. Disability in people affected by leprosy: the role of impairment, activity, social participation, stigma and discrimination. Glob Health Action. 2012;5:183-94.

12. SALSA Collaborative Study Group, Ebenso J, Fuzikawa P, Melchior H, Wexler R, Piefer A, et al . The development of a short questionnaire for screening of activity limitation and safety awareness (SALSA) in clients affected by leprosy or diabetes. Disabil Rehabil. 2007;29:689-700.

13. Organização Mundial de Saúde. CID-10, tradução do Centro Colaborador da OMS para a Classificação de Doenças em Português. 9 ed. rev. São Paulo: EDUSP; 2003.

14. Brasil. Ministério da Saúde, Secretaria de Vigilância em Saúde, Departamento de Vigilância Epidemiológica. Manual de prevenção e Incapacidades. 3. ed., rev. e ampl. - Brasilia: Ministério da Saúde; 2008. 140 p. (Série A. Normas e Manuais Técnicos) (Cadernos de prevenção e reabilitação em hanseníase; $n$. 1).

15. Oliveira MHP, Romanelli G. Os efeitos da hanseníase em homens e mulheres: um estudo de gênero. Cad Saúde Pública. 1998;14:51-60.

16. Duarte MTC, Ayres JA, Simonetti JP. Perfil socioeconômico e demográfico de portadores de hanseníase atendidos em consulta de enfermagem. Rev Latino-am Enfermagem. 2007;15:774-9.

17. Corrêa CMJ, Ivo ML, Honer MR. Incapacidades em sujeitos com hanseníase em um centro de referência do centro-oeste brasileiro entre 2000-2002. Hansen Int. 2006;31:21-8.

18. Opromolla DV, Nobrega RC, Gonçalves NNS, Padovani SHP, Padovani CR, Gonçalves A. Estimativa da prevalência da hanseníase pela investigação em demanda inespecífica de agências de saúde. Rev Saúde Pública. 1990;24:178-85.

19. Noordeen SK. Epidemiology and Control of Leprosy- a review of progress over the last 30 years. Trans R Soc Trop Med Hyg. 1993;87:515-7.

20. Costa RD, Mendonça VA, Penido RA, Lyon S, Costa AM, Costa MD, et al. Study of the profile of the neutrophin BDNF in new leprosy cases before, during and after multidrug therapy. Arq Neuropsiquiatr. 2011;69:100-4.

21. Barbosa JC, Ramos JNA, Alencar MJF, Castro CGJ. Pós-alta em hanseníase no Ceará: limitação da atividade, consciência de risco e participação social. Rev Bras Enferm. 2008; 61: 727-33.

22. Bibliotecadigital.ufmg.br [Internet]. Moschioni C. Fatores de risco para incapacidade física anotados no momento do diagnóstico de 19.283 casos novos de hanseníase no período de 2000 a 2005, em Minas Gerais, Brasil. [dissertação]. Belo Horizonte (MG) Faculdade de Medicina - UFMG; 2007. 89p. [citado 30 Abr 2014]. Disponível em: http://www.bibliotecadigital.ufmg.br/dspace/bitstream/ handle/1843/ECJS-77EN5C/cristiane_moschioni.pdf?sequence $=1$
23. Lana FCF, Amaral EP, Franco MS, Lanza FM. Deteç̧ão da hanseníase no vae do Jequitinhonha - Minas Gerais: redução da tendência epidemiológica ou problemas operacionais para o diagnóstico? Hansen Into. 2004; 29:118-23.

24. Reis FJJ, Gomes, MK, Cunha AJLA . Avaliação da limitação das atividades diárias e qualidade de vida de pacientes com hanseníase submetidos à cirurgia de neurólise para tratamento das neurites. Fisioter Pesq. 2013;20:184-90.

25. Bibliotecadigital.ufmg.br [Internet]. Moura SHL. Avaliação de incapacidades físicas e transtornos psicossociais em pacientes com hanseníase em Centro de Referência de Minas Gerais. [dissertação]. Belo Horizonte (MG): Escola de Medicina da Universidade Federal de Minas Gerais; 2010. 196 p. [acesso 22 Abr 2010]. Disponivel em: http://www.bibliotecadigital.ufmg.br/dspace/bitstream/ handle/1843/BUOS-8M4FQB/mestrado_silvia_helena_lyon_de_moura_med. trop..pdf? sequence $=1$

26. Bibliotecadigital.ufmg.br [Internet]. Mangueira J0. Incapacidades físicas, limitação da atividade e da participação social em pessoas no momento pós-alta de hanseníase em Fortaleza/CE. [dissertação]. Fortaleza (CE): Universidade Federal do Ceará; 2009. 94p. [acesso 19 abr 2015]. Disponível em: http://www.repositorio.ufc.br/bitstream/riufc/6971/1/2009 dis jomangueira.pdf

27. Barbosa JC. Pós-alta em hanseníase no Ceará: olhares sobre políticas, rede de atenção à saúde, limitação funcional, de atividades e participação social das pessoas atingidas. [tese]. São Paulo (SP): Universidade de São Paulo; 2009. 196p.

28. Ikehara E, Nardi SMT, Ferrigno ISV, Pedro HSP, Paschoal VD. Escala Salsa e grau de Incapacidades da Organização Mundial de Saúde: avaliação da limitação de atividades e deficiência na hanseníase. Acta Fisiatr. 2010;17:169 -74.

29. Shumin C, Diangchang L, Bing L, Lin Z, Xioulu Y. Assessment of disability, social and economic situations of people affected by leprosy in Shandong province. People's Republic of China. Lepr Rev. 2003;74:215-21.

30. Pergamum.univale.br [Internet]. Morais SG. Avaliação das ações de controle de hanseníase no município de Governador Valadares, Minas Gerais, Brasil, no período de 2001 a 2006. [dissertação]. Governador Valadares (MG): Faculdade de Ciências da Saúde da Universidade Vale do Rio Doce; 2010. 70 p. [acesso 6 jun 2015]. Disponível em: http://www.pergamum.univale.br/pergamum/tcc/ Avaliacaodasacoesdecontroledehanseniasenomunicipiodegovernadorvaladaresbrasilnoperiodode2001a2006.pdf.

\author{
MAILING ADDRESS: \\ Luciane Fernanda Rodrigues Martinho Fernandes \\ Av. Maria de Santana Borges, 1.600, casa 11 \\ 38055-000 - Uberaba - MG \\ Brazil \\ E-mail: fernandes.luciane62@gmail.com
}

How to cite this article: Reis BM, Castro SS, Fernandes LFRM. Limitation of activity and restriction of social participation in relation to age, gender and education in people with leprosy. An Bras Dermatol. 2017;92(3):335-9. 